\title{
EXAMINING THE DECLINE IN THE ECONOMIC OUTCOMES OF HIGHLY EDUCATED RECENT IMMIGRANTS TO CANADA
}

by

Muzna Qidwai, BSc (Honours), University of Toronto, 2015

\author{
A Major Research Paper \\ presented to Ryerson University \\ in partial fulfillment of the \\ requirements for the degree of \\ Master of Arts \\ in the Program of \\ Immigration and Settlement Studies
}

Toronto, Ontario, Canada, 2016

(C) Muzna Qidwai 2016 


\section{AUTHOR'S DECLARATION FOR ELECTRONIC SUBMISSION OF A MRP}

I hereby declare that I am the sole author of this MRP. This is a true copy of the MRP, including any required final revisions.

I authorize Ryerson University to lend this MRP to other institutions or individuals for the purpose of scholarly research.

I further authorize Ryerson University to reproduce this MRP by photocopying or by other means, in total or in part, at the request of other institutions or individuals for the purpose of scholarly research.

I understand that my MRP may be made electronically available to the public 


\title{
EXAMINING THE DECLINE IN THE ECONOMIC OUTCOMES OF HIGHLY EDUCATED RECENT IMMIGRANTS TO CANADA
}

\author{
Muzna Qidwai, 2016 \\ Master of Arts \\ Immigration and Settlement Studies \\ Ryerson University
}

\begin{abstract}
Canada has a long established history of accepting immigrants from diverse ethno-racial backgrounds to meet the labour market needs in the "knowledge based economy". However, since the 1980s, there have been declines observed in the economic success of recent cohorts of immigrants. At the same time, there has been a shift in source country composition towards nontraditional source regions in Asia, Africa, Southern and Eastern Europe. This shift has been accompanied by an increase in the human capital of immigrants, in terms of their educational qualifications and work experience as a by-product of the new points system. An explanation for the economic decline is that the institutional barriers of prejudice and discrimination have barred recent immigrants from access to high skilled employment. Nevertheless, one should also consider the massive restructuring of the labour market and its effects on the most vulnerable cohorts: immigrants; women; racialized people and youth.
\end{abstract}

Key words: immigrants; cohort effects; foreign experience; income differential 


\section{ACKNOWLEDGEMENTS}

I would like to thank my MRP supervisor, Professor Grace-Edward Galabuzi, for encouraging me to pursue this research topic. I would also like to thank my second reader, Professor Carmen Schifellite, whom I was lucky enough to work for as a Teaching Assistant in the past semester.

I would also like to thank my brother, Mohammad Uzair Qidwai, for editing my work and providing me with feedback that helped me in the completion of this project. 


\section{DEDICATIONS}

I would like to dedicate this research paper to my parents, Mohammad Mubashir Quidwai and Humera Nasreen for their continuous support and guidance.

I would also like to dedicate this paper to my sisters, especially Tooba Qidwai Ishtiaq, without whom this journey would not have been possible.

Furthermore, I would also dedicate this paper to both my grandmothers and thank them for their words of encouragement. 


\section{TABLE OF CONTENTS}

Title Page

Author's Declaration Page

Abstract

Acknowledgements

Dedication

Introduction

Section 1: Theoretical Frameworks

- Human capital theory

- The labour market segmentation approach

- Social capital theory

Section 2: Evolution of the Points System

Section 3: Methodology

- Limitations to research

Section 4: Understanding the deteriorating economic conditions

- The role of the shift in source-country composition

- Devaluation of foreign education

- Devaluation of foreign experience

- Macro economic conditions

Section 5: Discrimination in the Labour Market

Discussion and Conclusion

- Policy recommendations 


\section{Introduction}

This research paper will investigate a specific area of public policy concern -the issue of the decline in the labour market outcomes of recent cohorts of highly skilled immigrants in Canada. The goal of this paper is to evaluate the effectiveness of the points system, in terms of assessing whether immigration has spurred economic growth in general for immigrants. In recent years, immigration policy has placed an increased emphasis on the selection of highly educated immigrants to seek employment in the "knowledge-based" economy. Even though Canada has largely been successful in bringing in highly skilled workers, new immigrants have high levels of unemployment and lower earnings relative to native-born workers (Desjardins \& Cornelson, $2011,1)$. Therefore, the deteriorating economic outcomes of recent immigrants caused by the inadequacy of the labour market to incorporate new immigrants is of extreme significance to the policy makers (Desjardins \& Cornelson, 2011, 1). This study asks the following research questions: "Why has there been deterioration in the employment success of recent immigrants despite an increase in their skills and educational attainment? What role has been played by discrimination in the economic integration of ethno-racial groups in the Canadian labour market? And how can we improve the labour market outcomes of recent cohorts of immigrants?"

This paper will argue that a dramatic increase in educational attainment and a shift in skilled class had a little impact on improving the deteriorating economic outcomes among recent successive cohorts of immigrants. Recent immigrants to Canada from source countries of China, South Korea, Iran and Pakistan have a human capital advantage over other labour market entrants as they have attained university education (Adamuti-Trache, 2015, 190). Specifically, these immigrants from diverse ethno-racial backgrounds are highly competitive in the labour market as they hold degrees in the fields of science, engineering and healthcare that are 
extremely valuable to Canadian society (Adamuti-Trache, 2015, 191). Nevertheless, these internationally trained immigrants have faced a decline in their employment success in recent years, compared to earlier cohorts of immigrants (Reitz, 2001, 580, Reitz, 2007, 38). This may have occurred as a result of regulatory institutions and employers who denied immigrant's access to highly skilled occupations by attaching lower labour market value to foreign experience. Furthermore, it may have also occurred due to the inability of Canadian employers to assess the quality or relevance of immigrants' foreign qualifications (Bauder, 2003, 699). According to McMohan (2013), Minister Jason Kenney stated "its impossible to calculate the opportunity cost of productivity, the cost to our economy, represented by the unemployment and underemployment of immigrants". This has signified that skill discounting is a huge problem as it has adverse effects upon the Canadian economy due to its failure to successfully incorporate highly educated immigrants to the labour market.

This paper will be divided into five sections. In the first section, the three main theoretical frameworks of human capital theory, the labour market segmentation approach and social capital theory will be used to explain the segmentation of immigrants into low wage employment with precarious working conditions. The second section will evaluate the main economic goals of Canadian immigration policy since the formation of the points system to determine the current and potential immigration goals. The third section will discuss the potential causes that have led to the decline in economic outcomes of recent immigrants. The fourth section will investigate the prevalence of ethno-racial discrimination in the labour market to explain the declining earnings and unemployment conditions. The last section will provide policy recommendations that can be used to improve the labour market outcomes among newly arrived immigrants. 


\section{THEORETICAL FRAMEWORK}

\section{Human capital theory}

Human capital theory was originally developed through the work of economist 'Gary Becker (1964)' and it is considered the most productive approach to use to understand the deteriorating economic conditions of recent immigrants (Samers and Sniders, 2015, 165). The term "human capital" can be conceptualized as referring to the educational qualifications, work experience, language fluency, skill level and other capacities of an individual. In economic terms, 'human capital' refers to the future earnings potential of an individual worker. This theory has argued that the labour market outcomes of immigrants can be determined by the "education, skill level and other capacities of an individual combined with their aspirations and choice in terms of earnings, status and job conditions" (Samers and Sniders, 2015, 165). This suggests that highly skilled immigrants with high levels of educational attainment, work experience and knowledge of one of Canada's official languages will have favourable labour market outcomes, compared to other migrants who lack human capital (Phythian, Walters \& Anisef, 2010, 131). Although it is reasonable to assume that the human capital factors of education, work experience and language ability of an individual would have some effect on the earnings of immigrants, this case does not hold for recent immigrants. Instead, research has established that there has been a growing earnings gap between immigrants and native-born workers, which suggests that not only do newly arrived immigrants start with lower initial earnings but they also have greater difficulty in catching up with native born workers over time (Banerjee and Lee, 2012, 205). According to the human capital theory, this income differential amongst immigrants and non-immigrants occurs due to the "poor quality" of immigrants, in terms of their lack of motivation or intelligence (Buzdugan and Halli, 2009, 368). Therefore, it becomes increasingly crucial to 
consider factors other than human capital such as age, gender, parental educational levels, generational differences, religious affiliation and ethnic background when considering the actual labour market outcomes of immigrants (Samers and Sniders, 2015, 166).

However, when a discrepancy exists between immigrants' foreign education and work experience and their actual earnings, it suggests devaluation of immigrants' pre-migration human capital. Canadian employers and professional organizations may attribute a lower value to recent immigrants skills due to the inability of assessing the quality of foreign credentials (Banerjee and Verma, 2009, 3). Furthermore, it may occur because of ethno-racial discrimination based on the skin colour or the nationality of an immigrant (Banerjee and Verma, 2009, 3; Samers and Sniders, 2015, 166). It is important to note that the devaluation of pre-migration human capital, particularly for immigrants from "non-traditional" source countries, has a negative influence on the skilled workers and the immigrant-receiving country (Banerjee and Lee, 2012, 205). For immigrants entering Canada under the category of skilled worker class, their devaluation of human capital becomes a significant source of stress as it affects their ability to find employment that matches their qualification (Banerjee and Verma, 2009, 3). Interestingly, highly skilled immigrants are forced to seek low wage employment with precarious working conditions that is unrelated to their education or work experience (Samers and Sniders, 2015, 166). On the other hand, devaluation of immigrant labour also has an adverse effect on the immigrant receiving country, as it cannot benefit from the internationally acquired knowledge and skills of highly skilled workers (Banerjee and Lee, 2012, 205). Thus, it has been proposed that one important way for recent immigrants to facilitate their labour market integration is by engaging in further education after arrival to Canada. This form of human capital investment would provide new immigrants with an opportunity to gain Canadian specific knowledge, to obtain other specific 
skills that are better recognized by Canadian employers and to form important social networks through interaction with native born students and faculty (Banerjee and Verma, 2009, 4). However, it is important to consider that not all recent immigrants have the opportunity to further invest in their skills through engagement in educational courses and programs. This may be because of limited financial capital, lower language proficiency in English or French and skill discounting (Banerjee and Verma, 2009, 4).

Although the human capital theoretical framework is a useful approach, it is subject to certain limitations. Human capital theory relies on presumptions about migrants. For example, it holds the assumptions that an immigrant's language skills cannot be changed. In actuality, the language skills of an individual can be improved, which can result in a gain in their human capital (Samers and Sniders, 2015, 168). Moreover, human capital theory does not examine how changes in the immigration policy affect the economic performance of immigrants (Samers and Sniders, 2015, 168). Likewise, by employing quantitative data based solely on the effect of education and experience on immigrants' earnings, this theoretical orientation does not investigate institutional barriers such as prejudice and discrimination (Samers and Sniders, 2015, 168). Lastly, human capital theory is problematic in that it relies on national data even though the employment conditions vary in each region or sub region within a country (Samers and Sniders, $2015,168)$

\section{The Labour Market Segmentation Approach}

Labour market economists such as David M. Gordon, Richard Edwards and Michael Reich (1982) can be credited with the development of the labour market segmentation approach. This theoretical orientation has challenged the tenets of neoclassical economic theory and human capital theory by arguing that there is no formal mechanism in place that ensures that workers are 
matched to jobs according to their skill level (Bauder, 2001, 38). Instead, the process of labour market segmentation occurs within a framework in which "political economic forces encourage the division of the labour market into separate submarkets or segments, distinguished by different labour market and behavioural rules" (Reich, Gordon \& Edwards, 1973, 359). Thus, the central argument of this theoretical orientation is that forces arising out of political economy dynamics have resulted in the division of the labour market into separate segments with different working conditions and behavioural rules. This division results out of four segmentation processes that include: segmentation into primary and secondary markets, segmentation within the primary sector, segmentation by race and segmentation by sex (Reich et al., 1973, 359-360). Of particular relevance to our topic are the processes of segmentation of the labour market into primary and secondary markets and those along race and gender lines.

This theoretical orientation had originally argued that the labour market has been split into a primary and secondary sector that can be essentially differentiated by reference to stability characteristics (Reich et al., 1973, 359). The primary sector can be described as containing high paying, stable jobs with significant opportunities for promotions and pleasant working conditions. In contrast, the secondary sector can be characterized by relatively low paying, unstable jobs that offers fewer opportunities for promotion (Lusis \& Bauder, 2010, 30). However, recent segmentation models have argued against a dual split, suggesting that the labour market has been split into tripartite or quadruple models in accordance with hierarchal segmentation (Bauder, 2001, 38).

Secondly, this theory has emphasized that labour market segregation occurs on the basis of race, as racialized individuals are consigned to jobs in the lower segments of the labour market (Reich et al., 1973, 360). This segmentation into high paying and low paying sectors can be seen 
in the recruitment strategies of employers who utilize prejudicial stereotypes and characteristics of an immigrant's nationality to hire and promote workers (Samers and Sniders, 2015, 170). An important indicator of the existence of racial discrimination in employment is the concentrations of racialized groups in certain sectors of the economy in the context of the $21^{\text {st }}$ century Canadian labour market. The data provided by 2001 Human Resources and Skills Development Canada has revealed that racialized groups were excessively concentrated in low paying jobs such as machine operators, in the manufacturing industry and as labourers in the textile industry. Whereas, racialized groups were under represented in high paying occupations of senior managers, professionals, supervisors and trade workers (as cited in Teelucksingh \& Galabuzi, $2005,16)$.

Lastly, segregation into the employment sectors also occurs by sex as certain jobs have been reserved for racialized men while others have been reserved for racialized women (Reich et al., 1973, 360). For example, racialized women were two times more likely to be employed in clerical or sales positions as opposed to racialized men who were three times more likely to work as senior managers (Teelucksingh \& Galabuzi, 2005, 17). This indicates that racialized females have lower earnings as they tend to be employed in sectors that are oriented towards providing services to people (Reich et al., 1973, 360).

Although the labour market sectors appear to be functionally dependent upon each other, each sector has its own rules in relation to pay, working conditions and opportunities for promotions. These rules that appear to be controlling labour market behaviour prevent workers from switching between the sectors (Lusis \& Bauder, 2010, 30). Furthermore, cultural factors have been identified that reinforce the severity of the boundaries between the labour market segments. This can be seen in the cultural practice of non-recognition of an immigrant's 
educational credentials and the cultural reliance on professionalism limits, both of which prevent highly skilled immigrants from seeking employment in the primary sector (Lusis \& Bauder, $2010,30)$.

A major weakness within the labour market segmentation approach is that even though it has established that "good" jobs are located in the primary sector and "bad" jobs are positioned in the secondary sector, it does not indicates the types of industries that constitute the primary and the secondary sector. The eight-sector typology of industries compiled by the Economics Council and Statistics Canada would be a more useful way to assess the skill requirements and the job quality of immigrants' employment in the labour market (Pendakaur, 2000, 15). In the typology, the sectors of information services and non-market services can generally be viewed as being comprised of "good" jobs, as they require high wage levels and higher rates of rewards and pay. On the other hand, the sector of consumer services that is comprised of employment in retail, personal services and food can generally be classified as having "bad" jobs since it has lower skills requirement and lower pay. More importantly, jobs in the distributive services can be positioned in the middle as they require average skill levels and provide average benefits (Pendakaur, 2000, 16).

\section{Social Capital theory}

Social capital is an important theoretical framework that can be found in developmental studies and in the work of academics, economists, geographers and sociologists (Lusis \& Bauder, $2010,32)$. Although the notion of social capital is typically hard to define, it has been commonly referred in association with social trust and associational networks. Social capital differs from other forms of capital, namely human capital and cultural capital, on the grounds that it is rooted in social relationships that lead to positive social policy outcomes (Galabuzi \& Teelcucksingh, 
$2010,6)$. The central tenet of social capital theory is that social networks and relationships in the form of formal and informal group memberships can allow individuals to have access to social capital. In particular, the social networks can provide information to recent immigrants on immigration laws, housing and employment in migrant source communities (Lusis \& Bauder, 2010, 33). In reality, recent immigrants are often disadvantaged in integrating into the society as they lack the social capital that is essential to obtain information about job opportunities (Reitz, 2007, 29).

Social capital is comprised of two important elements: social relationships and the quality of these relationships (Lusis \& Bauder, 2010, 33). Social relationships come in various shapes and forms that include bonding capital, bridging capital and linking social capital. On one hand, 'bonding capital' can be characterized as homogenous ties among individuals of the same nationality or ethnic origin. On the other hand, 'bridging capital' could include the formation of heterogeneous networks among individuals outside of the nationality, ethnic origin or minority status. Additionally, immigrant networks also are comprised of 'linking social capital' in which individuals have association with different degrees of power (Nakhaie \& Kazemipur, 2012, 420). Consequently, the amount and quality of the social relationships can be used to explain the decline in the labour market performance of recent immigrant, in terms of access to employment opportunities and the occupational attainment (Lusis \& Bauder, 2010, 30). It has been reported that strong connections maintained with family and immediate relatives can provide access to low status employment. Whereas, weak connections maintained with friends, acquaintances, teachers and employers can provide immigrants with access to high status jobs (Nakhaie \& Kazemipur, 2012, 420). However, recent immigrants often find employment that does not necessarily match their educational credentials or foreign work experience. Thus segmentation in 
the secondary sector occurs even prior to foreign-born immigrants arrival to Canada as their social networks are embedded in low wage employment (Lusis \& Bauder, 2010, 30).

Although social capital is particularly significant in finding employment, research has established that the factors of human capital, immigration policies and other institutional barriers such as discrimination also have a strong impact on the labour market integration of immigrants (Samerss \& Snider, 2015, 177). A major limitation present within social capital theory is that it solely emphasizes the role of co-ethnic or co-national networks of immigrants in finding employment opportunities. However, this theoretical framework does not consider how employers use their social networks to hire workers of the same nationality for low wage employment (Samers \& Snider, 2015, 177). It may be the case that immigrants who are employed in the sector draw upon their existing social networks of family and relatives to recruit workers to the lower sector of the economy. This form of recruitment strategy based upon the social networks of immigrants would likely benefit the ethnically based business owners by reducing their time and costs of finding a reliable workforce (Samers \& Snider, 2015, 177). Furthermore, another limitation with social capital theory is that it fails to critically examines the role of human smugglers or traffickers in tricking or forcing migrants to work in low wage jobs with poor working conditions (Samers \& Snider, 2015, 179). 


\section{BACKGROUND INFORMATION}

\section{Evolution of the points system}

Although a variety of goals such as humanitarian goals, social goals and goals related to foreign policy have appeared in the evolution of the Canadian immigration policy, these goals have been dominated by economic goals in the immigration policy. This paper will provide an overview of the main economic goals of Canadian immigration policy over different historical periods to determine the current and potential immigration goals. In adopting the terminology of Hawkins (1972), the economic goals can be further classified into short term goals, that include the "achieving benefits from meeting immediate shortages in the labour market" and long term goals such as "achieving demographic benefits, benefits from general immigrant characteristics such as flexibility and investment and trade flow benefits" (as cited in Green \& Green, 1999, 427).

\section{6-1966:}

In the post war period, the immigration policy was strongly influenced by an economic boom in Canada and changes in the international environment caused by the increasing participation of Canada in international affairs. In May 1947, Mackenzie King's statement before the House stated "The policy of the government is to foster the growth of the population of Canada by the encouragement of immigration. The government will ... ensure the careful selection and permanent settlement of such numbers of immigrants as can advantageously be absorbed in our national economy" (Kelley \& Trebilcock, 2010, 317). King's statement indicated an underlying source of tension between the two main goals of immigration policy. The statement supported long term objectives through the promotion of population growth and economic development and it championed short-term objectives by setting immigration levels in 
accordance with the 'absorptive capacity' of the economy (Green \& Green, 1999, 430). This suggests that the absorptive capacity of the economy to provide employment at nominal wages to newly arrived immigrants was tied to the ethnic or racial origin of the immigrants (Troper, 1993, 259). The Immigration Act came to be revised in 1952 as it "clarified and simplified immigration procedures and removed certain anomalies which have been brought to light during the continued movement of newcomers to Canada" (Hawkins, 1998, 101). The main provisions of the Act established that all persons seeking admission into Canada must be examined. It also created a list of prohibitive classes under which immigrants were barred from entering on the basis of "nationality, citizenship, ethnic group and occupation..." (Hawkins, 1998, 102). However, a concerning issue with the Immigration Act was the extent to which it conferred discretionary power to immigration officers who had the authority to limit the admission of a potential immigrant on the "probable inability to become readily assimilated" even after admission (Kelly \& Trebilcock, 2010, 332). This indicated that the Act was a non-transparent way for the Canadian government to discriminate against immigrants from non-preferred countries. ${ }^{1}$

During the post war-period, a high level demand for labour in the resource sector exerted pressure on the government to ease the hardened admissions criteria for immigrants from nonpreferred source countries. Thereby, a change occurred in the immigration policy in 1956 as the sponsorship rights that were originally reserved for immigrants from non- traditional source countries $^{2}$ were extended to immigrants from other parts of Europe (Green \& Green, 1995, 1011). This extension of sponsorship right was rationalized on the basis that sponsored relatives

\footnotetext{
${ }^{1}$ Non-preferred source countries are countries other than those in northern and western Europe; it could include countries in Asia, Africa, Central America, Eastern and Southern Europe.
} 
would have high levels of skills that would be similar to their sponsors and that sponsorship rights of immigrants would be equally exercised across the countries. In reality, landed immigrants from non-traditional European source countries were more likely to sponsor their relatives than immigrants from preferred source countries, which led to an influx of unskilled, sponsored immigrants (Green \& Green, 1995, 1011). Subsequently, this led to a conflict between both the departments dealing with immigration, namely Citizenship of Immigration and Department of Labour (Green \& Green, 1999, 430). On one hand, Citizenship and Immigration took a long-term view as they argued that the immigration was beneficial for fulfilling demographic needs in the long run. On the other hand, Department of Labour took a short-term view in which they tied immigration to business cycle effects as they mainly argued that immigration should be restricted during times of slowed economic activity (Green \& Green, 1999, 430). An initial solution to solve the problem of a large unskilled inflow came through an Order-In-Council in March 1959, in which the government attempted to reverse the change in immigration policy by restricting the sponsorship rights of landed immigrants from Europe. However, this regulation caused uproar in the immigrant community, which they demonstrated through different forms of lobbying. This led the government to withdraw the Order in Council shortly afterwards in April 1959 (Green \& Green, 2004, 115).

Since 1962, the government has implemented immigration regulations in an attempt to increase the number of skilled workers and to remove racial discrimination from the immigration policy in Canada (Kelley \& Trebilcock, 2010, 338). Initially, the 1962 regulations made substantial changes to the admissibility criteria of the non-sponsored class of immigrants such that the factors of race and class no longer played a significant role in determining the selection of immigrants. Instead, admission was granted to a person "who by reason of his education, 
training, skills or other special qualifications is likely to become successfully established in Canada" (Kelley \& Trebilcock, 2010, 338). Moreover, admission was also granted to those who had the means to successfully establish themselves by having adequate means to either secure employment or support himself or herself during their stay in Canada (Kelley \& Trebilcock, 2010, 338). These selection standards suggested that the short-term view pioneered by the Department of Labour that linked the level and composition of immigration to immediate needs of the labour market had taken precedence in the immigration policy. However, shortly afterwards, the Department of Citizenship and Immigration and Department of Labour were amalgamated into the Department of Manpower and Immigration in 1966, which later reaffirmed the short-term view of immigration (Green \& Green, 1999, 431). Although the government aimed to eradicate racism from the immigration policy, it feared that expanding the sponsorship rights for all immigrants would lead to an influx of unskilled immigrants from non-European countries. Therefore, the government reserved the right to sponsor a wide range of relatives for Canadians from preferred European source countries (Kelley \& Trebilcock, 2010, 338). Still, the selection standards were not well specified which caused these regulations to give wide discretionary powers to the overseas immigration officers in determining the interpretation of the skills (Green \& Green, 1999, 431).

\section{7-1985}

However, the ultimate solution to control the skill level and the occupational composition of entering immigrants came through the creation of the points system in 1967. The points system required all applicants to be assessed on an objective scale on the categories of "age, education, training, occupational skill in demand, knowledge of English or French" and other factors in order to gain admissibility in Canada (Kelly \& Trebilcock, 2010, 361). The 1967 
points system suggested that immigration could be 'micro-managed' as immigration was to be used as a means for meeting immediate labour market needs (Green \& Green, 1999, 431-32). This system could be monitored as the points allocated to specific occupations were to be constantly assessed and modified, based upon the availability of new information on vacancies. However, the short term view that stressed an applicant's short term success in an intended occupation in the immigration policy was to be balanced with long term adjustment factors, such as age, education, etc. (Green \& Green, 1999, 432). A key feature of the points system was that it eliminated any distinction between the sponsorship rights of Canadian citizens and landed immigrants as it created three separate classes of immigrants: the independent, sponsored and nominated classes (Kelly \& Trebilcock, 2010,361). Of particular relevance in this work is the category of nominated relatives as it included of more 'distant' relatives of the Canadian citizens and landed immigrants. The nominated relatives were evaluated on the factors of "education, personal assessment, occupational demand, occupation skill and age"; while the other factors were disregarded for this class of immigrants based on the presumption that the nominator would assist the nominated relative in establishing himself or herself in Canada (Kelly \& Trebilcock, 2010, 362). Also, there was no formal quota established in the points system, which implied that an immigrant who passed the points criteria was to be admitted into the country, regardless of the number of immigrants who had previously been accepted (Kelly \& Trebilcock, 2010, 362). Lastly, the points system considerably reduced the discretionary powers of the immigration officers by providing them with a set of clear guidelines in determining the types of skills needed to establish whether the applicant met the skill requirements (Green \& Green, 1999, 432). Thus, it is worth emphasizing that the points system was an economic policy tool designed to shift the 
composition of the inflow of immigrants through the selection of immigrants with high levels of skills who were believed to be in demand in Canada.

During the large business cycle effects in the early 1970s, the levels of immigration were attuned to these fluctuations such that immigration levels fell between the years of 1974-78, increased from 1978-80 and then fell again from 1980-86 (Green \& Green, 1999, 432). The new regulations were largely unsuccessful in reducing the number of unskilled workers admitted because applicants could be admissible if they met the minimum points on "years of schooling, age and language" that were required for admission (Green \& Green, 1999, 432). As a result of this, the government placed increased restrictions on the immigration policy in an attempt to regulate the composition and the skill level of the inflow. By 1974, the change culminated in new rules, which indicated that all independent applicants seeking admission into Canada for the purposes of employment had to have a job offer or occupation in demand. The consequences of being unable to meet the requirements were severe since not having pre-arranged employment resulted in a 10-unit penalty; at the same time while failing to fulfil at least one unit of assessment under the 'occupation in demand' resulted in an automatic rejection of the application (Green \& Green, 1995, 1014). In 1976, a new immigration Act was introduced in Parliament that laid out the objectives of immigration policy. This new Act initiated a formal procedure that required the Minister to meet with the provinces and other institutions to discuss the future levels of immigration, which were later to be publically announced to the Parliament each fall (Green \& Green, 1995, 1014). Another important feature of the Immigration Act was its commitment to admitting a greater number of refugees on an annual basis, and this later change indicated that Canada's international obligations with respect to refugees had taken precedence in the immigration policy (Green \& Green, 1995, 1015). In 1978, a 'Canadians First' Policy was 
implemented that made it mandatory for employers to hire a foreign worker only in situations when Canadian citizens or permanent residents were not available or willing to take the job (Kelly \& Trebilcock, 2010, 391). During the recessionary period of May 1982, the Canadian First Policy took a stronger form as the government reaffirmed the requirement for independent immigrants to have pre-arranged employment in order to gain admissibility into Canada (Kelly \& Trebilcock, 2010, 392). All of this indicates that the short-term economic goals still held precedence in the period as the levels of immigration were adjusted accordingly with the macro economic conditions.

\section{6- 2002}

As the early 1980s recession reached an end, the government instigated a review of the immigration policy whose conclusions can be found in the special report to Parliament and the Annual Report to Parliament on Future Immigration Levels (Green \& Green, 1999, 432). The review of the immigration policy was mainly concerned with the occurrence of a decline in population growth that was seen to be related to immigration being maintained at its current low levels. Therefore, the review called for an increase in the economic component of the inflow, while warning that it should not occur at the cost of social and humanitarian streams (Green \& Green, 1999, 434). In acting upon the findings of the review, the government removed the provision of prearranged employment in January 1986 and it introduced further plans that sought to increase the assessed inflow. Additionally, the government expanded the business class by adding an investor's class, whose admissibility was determined on the ability to invest substantial amounts of money in Canadian businesses (Green \& Green, 1999, 434).

However, a demographic review of the immigration policy in 1989 discovered that the modifications made to the immigration policy are not adequate to address the consequences of 
declining birth rates. Beginning in the early 1990's, there was a shift in policy priority as the government moved away its focus on meeting demographic goals and worked towards increasing the economic component of the inflow. In May 1991, a 'designated occupations' list was created under which potential immigrants that matched the list by having occupations deemed to be in short supply in the specific provinces were prioritized in their admission to Canada (Green \& Green, 1999, 434). Subsequently, this was followed by the introduction of a new Immigration Act in 1992, which gave the government broad new regulatory powers. The 1992 regulations that accompanied the Immigration Act affirmed that immigration was to use a long-term policy tool as it divided the flow of immigrants into classes, which would determine the priority processing (Green \& Green, 1995, 1015). Due to the great level of difficulty associated with selecting immigrants whose occupations were in demand, the government moved towards a human capital model of selection. The human-capital based model of selection was successful in increasing the educational attainment of immigrants and specifically the proportion of immigrants in the economic class as they were seen as better meeting the needs of the labour market in the longer run (Ferrer, Picot \& Riddell, 2014, 849).

In 1995, the Liberal report titled 'Into the $21^{\text {st }}$ century: A Strategy for immigration \& Citizenship' identified specific strategies to be pursued in the future directions of immigration policy. The central tenet of the report was that immigration levels should be maintained at $1 \%$ of the population levels to meet the long-term demographic goals (Green \& Green, 1999, 435). The liberal document called for restrictions upon the family class applicants, other than for spouses and dependent children who enter under the objective of family reunification. The report also argued that long-term goals should take preference in the immigration policy as immigration can be used as an instrument to change the skill level of the labour market entrants. Lastly, the report 
called for the abandonment of the concept of "absorptive capacity" by admitting large inflows even during periods of high unemployment as it would benefit the long term demographic goals of immigration (Green \& Green, 1999, 435-36). All of these recommendations suggest that the government increased support for strengthening the economic component of the inflow based on the presumption that highly skilled immigrants would be able to better survive the fluctuations in the business cycle.

By the early 2000s, a change had occurred within the immigration system such that it now gave less attention to development in family and refugee classes while prioritizing the economic component of the inflow. The main goals of immigration embodied in the Immigration and Refugee Protection Act (IRPA) introduced in 2002 and other new immigrant programs were identified as the improvement of immigrant economic outcomes, responding effectively to immediate labour market needs and on a shift in immigration away from the three largest cities to other regions of the country (Ferrer et al., 2014, 848). In particular, through the implementation of IRPA, the government strengthened the human capital model of selection in the Federal Skilled Workers Program (FSWP), which would assist in selecting highly skilled immigrants. The motivation behind this move was that rewarding skills rather than occupations in demand would lead to an improvement in long-term immigrant economic outcomes (Ferrer et al., 2014, 850). Since the mid-2000s, a shift has occurred in the goals of immigration policy due to the alarming need to address the occupational labour market shortages. These objectives have led the government to meet short term labour market needs through the development of new programs, as FSWP has been seen as a better fit to meet long term labour market needs. 


\section{METHODOLOGY}

This paper utilizes non-reactive qualitative and quantitative techniques of secondary analysis to explore the problem of declining economic outcomes of recent immigrants. Secondary analysis relies on secondary sources of information to pursue a research question that is often distinct from the original work (Hinds, Vogel \& Clarke-Steffen, 1997, 408). Although secondary analysis of quantitative data sets is seen as a commonly accepted approach, this study is a mixed study because it will utilize both quantitative and qualitative data sets from previously established literature. In particular, this study will focus on a concept in the analysis of documentation that has not been previously emphasized in the primary work (Hinds et al., 1997, 411). This method was chosen because it would allow research to be conducted in a timely manner, which was considered as a top priority for this research project. Furthermore, this research would not have issues with reactivity, which occurs when human participants behave differently as an outcome of being aware that they are being studied (Newman \& Robson, 2012, 292).

The first step in conducting the research project was to familiarize myself with the research topic by reading various articles, book chapters and other research papers. This orientation reading assisted in conceptualization of the preliminary concepts and in development a list of potential research questions that would be used to guide the research (Newman \& Robson, 2012,299). For the purposes of this paper, the "employment success" of immigrants was defined as the employment rate and earnings in comparison to the native born population. The research questions most relevant to this project are:

1. Why has there been deterioration in the employment success of highly skilled immigrants despite of the increased emphasis of human capital in the points system in Canada? 
2. What role has been played by discrimination in the economic integration of ethno-racial groups in the Canadian labour market?"

3. And how can we improve the labour market outcomes of recent cohorts of immigrants?

The second major step in this project was to explore previously established literature to locate the evidence that would answer the research questions. A wide variety of key terms were developed to guide the search process which included: immigrants, cohort effects, labour market outcomes, unemployment rate, wage-gap, income differentials, source country, foreign experience, quality of education, business cycle, ethno-racial discrimination and Canada. Initially, these terms were employed to look for peer-reviewed scholarly articles, reports, research papers, working papers, book chapters, government documents and news articles from Ryerson University Library \& Archives. Then, a librarian was also consulted for help in locating additional peer-reviewed articles from a wide variety of databases such as Canadian Periodical Index, Google Scholar, JSTOR, ProQuest, SAGE Journals, Scholars Portal Journals and Sociological Abstracts. Lastly, the references that were listed in the bibliographical section of the articles were also used to find highly relevant research.

Once all the sources were gathered, they were assessed on the relevance to the topic and the author's credentials and a determination was made about including them in the research paper. During the initial reading process, the literature was quickly skimmed through to get an understanding of the purpose of these studies. Then, several sections of the articles were highlighted and brief notes were jotted down in the margins to emphasize the stimulating or interesting aspects of the paper. These annotations were then developed into extensive notes in an attempt to restate the central ideas of the authors into my own words. An important feature of the note taking stage was that concepts were constantly modified and new research questions 
were developed from the recent evidence that emerged from the literature. Additionally, a bibliography list with complete citations was also created to keep a track of all the sources used.

In the third step of the research project, research sources were evaluated on their significance in answering the key research questions. Furthermore, the gathered evidence was also evaluated on its ability to meet the criteria of accuracy, reliability and the strength of the argument. The evaluation stage was helpful in narrowing down the selected research sources for the completion of the project. This occurred as the articles deemed as relevant were selected for the writing of the research project, whereas those articles that were found to be irrelevant were discarded. Later, the literature was used to create an outline that was comprised of important elements of an introduction, main arguments and its supporting evidence, and the elements of a conclusion.

The fourth stage of the research article was to summarize and synthesize the gathered evidence from a wide array of sources. The evidence was integrated into the arguments of the research paper to communicate information to the readers in a meaningful way. This was followed by the discussion of the findings and conclusion that attempted to identify the research gaps and highlight areas of future research. The last step of the research paper was to revise the document by reading and re-reading several times to ensure that there were no grammatical errors present within the paper.

\section{Limitations to research}

This major research paper was strengthened as it investigated in-depth the problem of deteriorating economic outcomes of highly educated immigrants by taking a historical overview of the evolution of the points system. It was important to examine the main economic goals that have been addressed by immigration policy over Canada's history to determine the current goals 
of the immigration policy. However, this research paper was subjected to certain limitations due to the nature of its scope. First, this paper only examined the economic outcomes of highly educated immigrants who entered under the skilled class, rather than those who entered other economic streams such as the Federal Skilled Worker Program (FSWP) and Provincial Nominee Program (PNP). Second, this paper did not compare the labour market outcomes of economic immigrants with those who entered as family class immigrants and refugees. Third, this paper did not examine factors that can mitigate high rates of poverty among recent immigrants and contribute to their successful employment conditions. Lastly, this paper relied only on secondary sources that have already been published in books, journal articles and research papers and working papers. 


\section{FINDINGS}

\section{Understanding the deteriorating economic conditions}

In the past, a defining feature of Canadian immigration policy was that it was set in accordance with the needs of the labour market. Green (2004) stated that an increase in immigration levels would be observed in periods of economic expansion while a reduction in immigration levels would occur during economic downturn (as cited in Hou \& Picot, 2014, 7). However, since the early 1990s, high levels of immigration have been maintained independent of economic recession (Hou \& Picot, 2014, 7). Therefore, Canadian immigration policy has received public attention in recent years as it has led to the less effective integration of highly skilled immigrants into the Canadian labour market. Research has revealed that the employment rate and the earnings of recent cohorts of immigrants have weakened throughout the 1970s, 1980s and the beginning of the 1990s (Ayedemir \& Skuterud, 2005, 642). The unemployment rate was observed to be at a low of $5.1 \%$ in 1980 s, it rose drastically upwards to a high of $9.9 \%$ in 1983 , declined to $6.3 \%$ in 1989 , peaked at $10.7 \%$ in 1992 , after which it dropped to $5.7 \%$ by 2000 for the core aged working group of immigrant men (Frenette \& Morisette, 2003, 6). Moreover, the earnings of immigrant men deteriorated significantly by $13 \%$ to $31 \%$ in $1980-85$, stopped weakening between 1985-90, fell again by 45\% in 1995 and then improved shortly afterwards (Frenette \& Morisette, 2003, 7). Similarly, immigrant women witnessed deterioration in their earnings by $20 \%$ to $32 \%$ between $1980-85$, improved slightly between $1985-90$, weakened between 1990-95 and improved shortly afterwards (Frenette \& Morisette, 2003, 7).

These trends observed for the deterioration in immigrant earnings has long term implications for earnings convergence between immigrants, as it indicates that it will take longer for immigrants earnings to converge with those of native born workers. These findings are also a 
matter of great concern to the policy makers as it indicates that recent immigrants experience diminished earnings despite having high levels of human capital. Furthermore, these findings also challenge the emphasis of educational attainment in the points system since the host country does not benefit from these highly skilled immigrants in the knowledge-based economy (Ayedemir \& Skuterud, 2005, 642).

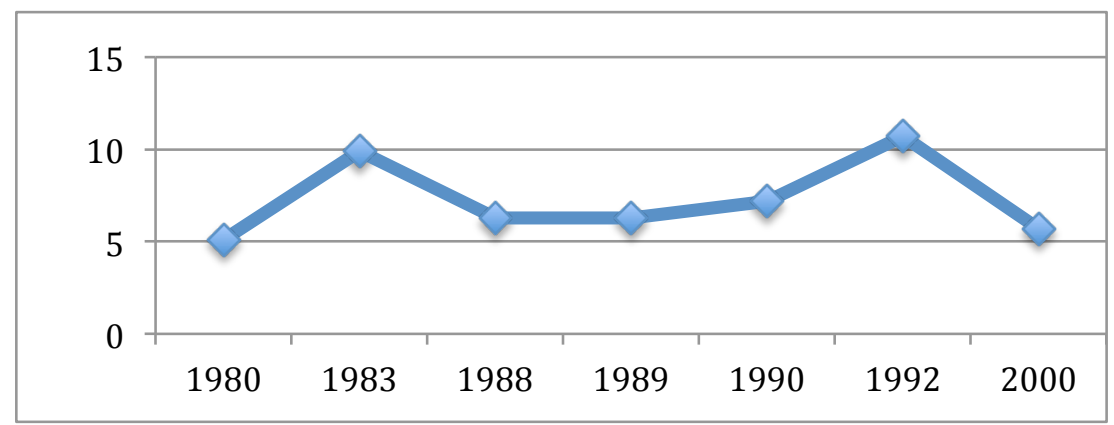

Table 1: immigrants unemployment rate

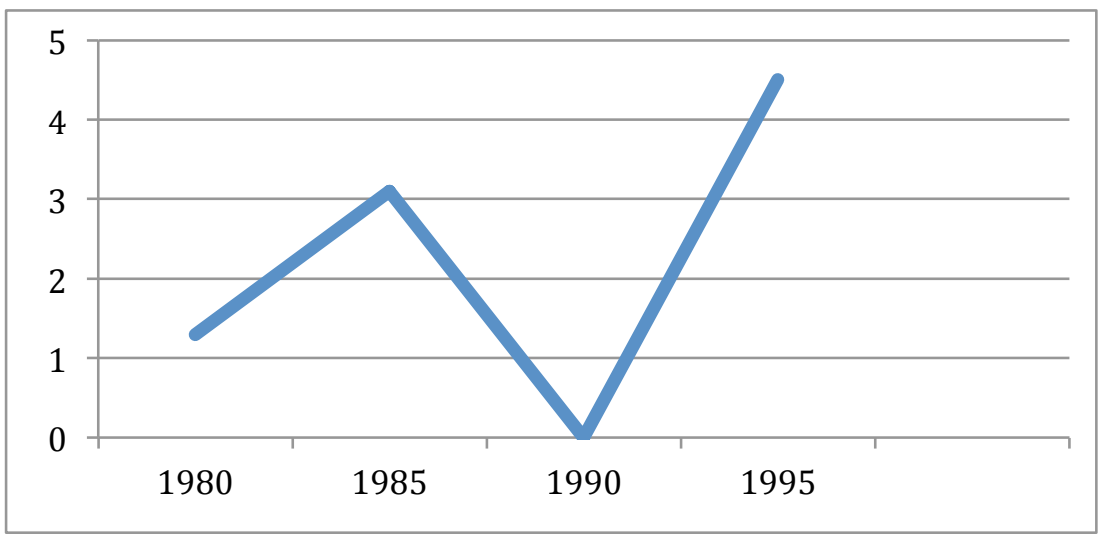

Table 2: Decline in immigrants earnings

\section{The role of the shift in source-country composition}

One explanation provided by researchers is that the decline in earnings has occurred because of the remarkable shift in immigration away from traditional source regions in Europe toward non-traditional source countries in the Asia, Africa, Caribbean and Latin America (Reitz, 2007, 48). This shift in the source country composition of immigrants that has occurred has occurred mainly during the period of 1967 to 1980 , as a direct response to the points based 
system in 1967 (Reitz, 2007, 48). This trend has continued from 1980 onwards, as there has been a reduction in the proportion of immigrants from the U.S. and North and Southern Europe, while an increase has been observed in immigrants from Asia, Africa and Eastern Europe (Picot \& Sweetman, 2005, 16). Despite having high levels of skill and educational attainment, recent immigrants from these non-traditional source regions have lower earnings in the host country. This may occur because the human capital of immigrants acquired in non-English speaking source countries may not be easily transferrable to the Canadian labour market (Picot and Sweetman, 2005, 16). As a result, recent immigrants from non-traditional source regions are forced to learn new forms of skills or trades in order to facilitate their integration in the Canadian labour market (Roy, 1997, 157). Aside from the source country composition, other possible factors such as educational quality and relevance, language ability, and large cultural differences may also contribute to the declining earnings of recent immigrants (Picot and Sweetman, 2005, 16).

The role of language ability, associated with the shift in source country, is an important factor than can explain diminishing immigrant earnings. It can be argued that immigrants whose mother tongue or home language is not English or French would tend to have poorer local language ability. As language skills are related to the productivity of an individual, limited language ability in either one of Canada's official languages would in turn have a negative impact on immigrant's earnings (Picot and Sweetman, 2005, 16). Surprisingly, Ayedemir \& Skuterud (2005) have reached the conclusion that changing language abilities can have only a small role in this issue. This can be seen as among the 1995-99 cohort, changing language abilities contributed to a $4 \%$ decline in male immigrant earnings, while it led to a $2 \%$ decline in female earnings (Ayedemir \& Skuterud, 2005, 655). However, a much larger role can be 
attributed to the shifts in source country composition in explaining the deteriorating entry earnings, particularly for immigrant men. This can be evidenced as earnings declined for immigrant men from $30 \%$ to $23 \%$ in the $1990-94$ cohort and from $23 \%$ to $15 \%$ in the $1995-99$ cohort, contributing to a 7\% decline in each cohort (Ayedemir \& Skuterud, 2005, 656) Their findings altogether suggest that roughly "one-third of the long-term decline of the entry earnings can be explained by compositional shifts in language abilities and region of birth" as described in the beginning of this section (Ayedemir and Skuterud, 2005, 656).

\section{Devaluation of foreign education}

Since the reform of the immigration policy in 1967, education levels have increased among immigrants because of the greater emphasis on the human capital in the points based selection system (Reitz, 2007, 49). Simultaneously, in the period from 1970s to 1990s, there has also been an increase observed in the education levels of native-born Canadians due to the greater public investment in education (Reitz, 2007, 49). Therefore, it becomes reasonable to assume that increasing levels of education would result in greater valuation of educational credentials for both the groups of native-born Canadians and immigrants. In actuality, only native-born Canadians have benefitted from the rising levels of education, in terms of finding employment that matches their educational credentials (Reitz, 2007, 49). The escalation in education levels of native-born Canadians has created competition amongst the workforce, which in turn has negatively impacted the labour market outcomes of immigrants. According to Reid (2001), the rise in the education levels of the native-born workforce can potentially explain "one-quarter of the decline in employment earnings between the later 1970s cohort and the cohort arriving in the late 1980s" (as cited in Reitz, 2007, 49). Aside from the rising levels of education in the workforce, the devaluation of immigrants' foreign education can also explain the deterioration in 
immigrants' earnings. Even though the educational credentials of immigrants are equal or comparable to those of native-born Canadians, employers and regulatory agencies discount immigrants' human capital skills by failing to recognize them as equivalent to those of nativeborn Canadians ( $\mathrm{Li}, 2001,23)$. This has important consequences as immigrants with a foreign degree receive the lowest economic returns to their credentials due to the lower labour market value given to it, relative to native-born degree holders and immigrant Canadian or mixed degrees holders ( $\mathrm{Li}, 2003,32)$

Researchers have increasingly examined the labour market value of immigrant educational credentials, in terms of years of schooling and attainment of diplomas or degrees. This distinction is important as it allows for the assessment of a "sheepskin effect", which frames the worth of an educational credential independent of the number of years of schooling involved in obtaining the credential (Ferrer \& Riddell, 2008, 187). It has been discovered that a discrepancy exists in the value of immigrants' educational credentials amongst those from traditional source regions and non-traditional source regions. The value of immigrants' educational credentials from traditional source regions in the U.S, Northern and Western Europe is similar to those of native-born Canadians and based on their years of schooling. In contrast, immigrants from nontraditional source regions in Asia, Africa, Eastern and Southern Europe received lower returns for years of schooling than native-born workers (Picot \& Sweetman, 2005, 18). However, this devaluation of pre-migration educational quality of immigrants has a strong influence on the labour market earnings of immigrants, rather than source country itself (Sweetman, 2004, 9). In examining the impact of years of schooling and the perception of educational quality on immigrants' earnings, it has been revealed that the impact of years of schooling appears to be greater. This can be demonstrated as male immigrants with lower levels of education from 
countries with perceived high quality educational systems have lower earnings (Sweetman, 2004, 21). However, as there is an increase in years of schooling, the earnings of immigrants from source countries with perceived higher educational quality improve significantly. In contrast, an increase in "returns" to education does not seem to occur for immigrants from source countries with perceived lower quality educational system (Sweetman, 2004, 22). Furthermore, the source quality of immigrants pre-migration education credentials does not have an impact on those that immigrate at a young age, preferably under the age of 10 (Sweetman, 2004, 9). These younger immigrants receive a return to education that is similar to that of native born. Conversely, educational credentials do have a negative impact on the labour market earnings of immigrants who migrate at an older age, as it yields a lower economic return (Schaafsma \& Sweetman, 2001, 1067).

Even though foreign educated immigrants receive lower earnings based on the years of schooling, immigrants receive greater "returns" from completing a Canadian educational degree than the native born workers. This can be evidenced across all three levels of education including of high school, undergraduate and postgraduate levels. At the high school level, it was observed that the gains in earnings for immigrant men and women were slightly greater than those of native-born men and women. Whereas, at the university level, the gains in earnings for immigrant men and women were moderately larger, in comparison to their native born counterparts (Ferrer \& Riddell, 2008, 213) Upon further inspection, it was exposed that the European immigrants received the greatest returns, followed by immigrants from South America and Africa. However, immigrant men and women from South Asia received the lowest returns for their bachelor's degree (Ferrer \& Riddell, 2008, 211). Lastly, it has been reported that immigrants from all source regions were likely to benefit from the completion of a postgraduate 
degree, relative to native-born workers (Ferrer \& Riddell, 2008, 213). Therefore, it can be claimed that immigrants disadvantage in earnings due to devaluation of their educational credentials can be offset by completion of higher education in Canada.

\section{Devaluation of foreign experience}

The devaluation of foreign labour market experience can potentially provide another explanation for the lower earnings of immigrant men and women. The deskilling of immigrant credentials is commonly understood as a "naturally occurring adjustment period" in the host country (Bauder, 2003, 699). However, researchers have increasingly argued that this idea needs to be rejected in light of the fact that professional organizations and the state purposefully fail to recognize immigrants' foreign acquired experience that is similar to the experiences of Canadian born workers. The rationale behind the occupational downgrading of immigrants foreign credentials was to give preference to the native born and Canadian educated workers for high skilled occupations (Bauder, 2003, 699). Therefore, stringent certification systems have been out in place for a wide variety of occupations such as medicine, law, nursing, social work teaching that prevent foreign trained immigrants from obtaining Canadian accreditation (Bauder, 2003, 702). Thus, the lower labour market value attributed to immigrants international credentials has created a barrier between immigrant and Canadian labour as it has resulted in the segmentation of workers into low paying jobs in the secondary sector (Bauder, 2003, 702).

Closely related to this concept is the lack of "Canadian experience", which also contributes to the systematic exclusion of immigrants from high skilled occupations. The lack of Canadian experience was recognized as a barrier to employment as employers have a tendency to reject job candidates who show a lack of understanding of "local knowledge and knowledge of the Canadian systems" (Bauder, 2003, 711). This suggests that Canadian experience holds more 
value for recent immigrants, as it is a determining factor of their employment and labour market earnings (Buzdugan \& Halli, 2009, 376). Furthermore, lack of Canadian experience also leads to the systematic exclusion of immigrants from occupations that are not formally regulated by professional organizations (Bauder, 2003, 711).

Several studies have asserted that there have been significant decreases in the value of foreign experience for both immigrant men and women in the 1980s, 1990s and early 2000 (Aydemir \& Skuterud, 2005, 658; Green \& Worswick, 2002, 1). In the 1980s, recent immigrants received substantial "returns" on foreign experience that were similar to the returns obtained by the native born on their Canadian experience. However, this situation changed by the1990s as changes in the immigration law meant that the newly arrived immigrants received a zero return on their work experience acquired in the source county (Green and Worswick, 2002, 23). Both men and women experience substantial decreases on foreign experience among more recent immigrant cohorts. Amongst immigrant men in 1965-69 and 1995-99 cohorts, the deterioration in earnings at 10 years of work experience has been severe as it has declined from $1.3 \%$ to $0.1 \%$. However, the deterioration in earnings for their female counterparts is of less significance because the returns on foreign experience across all cohorts of immigrant women have been close to zero (Ayedemir \& Skuterud, 2005, 658). Moreover, the work experience of older immigrants was heavily discounted as older immigrants receive lower labour market returns on their foreign experience than Canadian born and Canadian educated immigrants who land at a young age (Picot and Sweetman, 2005, 19). Furthermore, this earnings disadvantage has occurred with each successive cohort of immigrants, as older immigrants in recent years have experienced a greater decline in their earnings, as compared to those who arrived in the late 1970s or early 1980s (Picot and Sweetman, 2005, 19). 
Shifts in the source country composition of immigration away from traditional source regions can potentially explain the economic decline in return to foreign experience (Green and Worswick, 2002, 18). Highly skilled immigrants from non-traditional source regions face a greater number of challenges in transferring their human capital to the Canadian economy. This occurs as immigrants have acquired skills from their foreign experience that are either less appreciated or not recognized by Canadian employers (Green and Worswick, 2002, 18). However, source country composition is not the only factor contributing to the decline as other factors might also contribute to the devaluation of immigrant labour. Ayedemir and Skuterud (2005) have in fact argued that compositional shifts make little contribution to the declining returns on foreign labour market experience. As it was previously indicated, a decline was observed in the earning of immigrants from non-traditional source regions in Asia and Africa for the 1995-99 cohort. Surprisingly, a decline was also observed in the returns on work experience for immigrants from the traditional source regions in the same cohort, although it was much weaker (Ayedemir \& Skuterud, 2005, 661). It was further suggested that the decline in the return on foreign experience might also occur because of a shift within regions, such as a shift away from economic class immigrants to refugees (Ayedemir \& Skuterud, 2005, 659). Therefore, these overall findings in relation to foreign experience suggest that "one quarter and one-half of the overall deterioration in entry earnings of immigrant men and women can be explained by declining wage returns to foreign experience" (Aydemir and Skuterud, 2005, 659).

\section{Macro economic conditions}

Over recent years, the Canadian labour force has become more precarious. There has been an increase observed in high-wage and low-wage employment, but a decline in middle-wage employment. This change has occurred in the labour market largely as big companies have 
reduced their workforces due to relocation, reorganization and technological change (PEPSO, 2013, 13). Precarious employment can be traced back to the 1970s in which a shift occurred in the economic growth away from manufacturing-based industry towards service and knowledgebased industries. As a result, a significant number of women entered into Canadian workforces as part-time or temporary labourers (Law Commission of Ontario, 2012, 12). However, since the mid 1980s, precarious employment became more prevalent as it extended into the knowledge based sectors of arts, media and communication. This change occurred as services that were generally managed by public service sectors were later contracted to not-for-profit agencies (PEPSO, 2015, 18). Canford, Vosko, Zukewich (2003) have reported that non-standard work grew in the 1990s and it stabilized in the latter half of the decade (8). By 2000s, only a small number of workers held full-time permanent jobs that provided high wages, job security and statutory benefits such as drug prescription or pension plans (PEPSO, 2013, 13). Many other workers worked in "part-time employment; temporary employment, including term or contract, seasonal, causal, temporary agency and all other jobs with a specific pre-determined date; own account self employment and multiple job holding" (Canford et al., 2003, 8). These forms of precarious employment can be characterized as low-wage employment with lower unionization rates, lower regulatory protections and a higher level of job uncertainty and insecurity (Canford et al., 2003, 9). Part-time employment is the worst form of precarious work as workers have lower wages, and no entitlement to union benefits and pension plans (LCO, 2012, 16). Similarly, temporary workers also experience lower wages, less union coverage and exposure to dangerous working conditions (LCO, 2012, 16). Interestingly, self-employed workers work long hours from home without entitlement to training or benefits. One important explanation offered for self 
employment to be categorized as precarious employment was that workers were generally pushed into it because of the difficulties associated with finding employment (LCO, 2012, 17).

Precarious employment appears to have significant effects on the most vulnerable cohorts of immigrants, racialized people, women, and youth. Recent immigrants to Canada have been “disproportionately affected by rising unemployment, reductions in full time work and a declining manufacturing base" (LCO, 2012, 21). As a result, newly arrived immigrants were more likely to experience precarious employment by being concentrated in part time temporary wage work (LCO, 2012,). Moreover, racialized workers have experienced employment precarity differently than white workers. Racialized workers reported an increase in precarious employment and a decrease in secure employment between 2011-2014. On the other hand, white workers reported a decrease in precarious employment and an increase in secure employment over the same time period (PEPSO, 2015, 30). In examining the racialized populations by ethnicity, it was discovered that Chinese and Filipino employees were more likely to have fulltime permanent wage work than white employees. Whereas, Black and South Asian groups were in 'non-standard employment' situation and they were less likely to have full time permanent wage work relative to white employees. A distinction even existed between the two groups as South Asian employees were heavily employed in full-time temporary wage work while Black employees were employed in part-time temporary wage work (Canford et al., 2003, 16).

Likewise, it has also been established that both sexes experienced precarious employment in different ways. On one hand, men were more likely to be engaged in less precarious work as they worked in full-time permanent and full-time temporary wage work. On the other hand, women were more likely to report more precarious employment as they were over represented in part-time permanent and part-time temporary wage work (Canford et al., 2003, 14). In examining 
the effect of precarious employment by sex and race, it was revealed that racialized men and white men were more likely to be employed in precarious employment, rather than secure employment (PEPSO, 2015, 31). This situation was also similar for racialized women as they reported an increase of $20 \%$ in precarious employment and a decrease of $10 \%$ in secure employment between 2011-2014. In contrast, white women were the only group to report a decrease in precarious employment and an increase in secure employment (PEPSO, 2015, 31). Precarious employment also had a greater effect on youth, as younger individuals had a higher likelihood of reporting full time permanent temporary wage work relative to middle-aged and older groups. However, the intersection of age with gender also produced unique social outcomes, as young women taken together were more likely to report part-time permanent wage work when compared younger men (Canford et al., 2003, 17). 


\section{DISCRIMINATION IN THE LABOUR MARKET}

One important factor that can account for deterioration in the economic outcomes of recent immigrants is discrimination on the basis of race or immigrant status. In the $21^{\text {st }}$ century, discrimination has been manifested through ways that "continue to deny racialized group members the attainment of their full potential in the Canadian labour market" (Teelucksingh \& Galabuzi, 2005, 6). However, it is important to note that discrimination in employment may include subtle ways of expressing negative behaviour towards members of a group, such as through the strategies of social exclusion and avoidance (Esses, Bennet-Abu Ayyash and Lashpina, 2014, 57). In economic discrimination, a lower value is assigned to immigrants' foreign credentials, due to the inability of employers to assess the value of their human capital skills. Whereas, in exclusionary discrimination, members of an ethno-racial group are not hired or not promoted in situations where they are hired (Teelucksingh \& Galabuzi, 2005, 6). Therefore, denying equal opportunity to all immigrants in employment has serious implications as it leads to the prevention of highly skilled individuals from successfully integrating into the Canadian labour market. In particular, the patterns of higher rates of poverty, sectoral segregation, higher rates of unemployment and a failure to convert human capital into high occupational status have been observed in immigrants and racialized populations (Teelucksingh \& Galabuzi, 2005, 7). The discrimination present in employment practices has important implications. First, it has a negative impact for the racialized populations as they are prevented from access to high-status jobs by being relegated to low wages jobs with dangerous working conditions. Second, the prevalence of discrimination has an equally negative impact on the Canadian economy as it fails to utilize the educational qualifications and foreign work experience of these highly skilled immigrants (Teelucksingh \& Galabuzi, 2005, 3). 
A reliable instrument that can be used to measure racial discrimination in Canada is the income disparity between racialized and non-racialized populations, which includes Canadianborn white, Canadian-born visible minority groups, immigrant white and immigrant visible minority groups. In comparing the earnings between immigrants and the native born population, it was revealed that immigrant white men earned similar to Canadian born white men as they only experienced an earnings gap of $2 \%$ between them (Pendakaur \& Pendakaur, 1998, 520). In contrast, immigrant visible minority men were subjected to an earnings gap of $16 \%$ in comparison to Canadian-born white men (Pendakaur \& Pendakaur, 1998, 520). This earnings gap between immigrants and Canadian-born workers may have occurred because of the difficulties associated with the transference of human capital from source countries to the Western countries. If so, it is reasonable to assume that this earnings gap should disappear as immigrants learn new skills or trades to facilitate their integration into the Canadian labour market (Pendakaur \& Pendakaur, 1998, 544). In actuality, it has been reported that the visible minority immigrant men do not receive similar "returns" on their human capital investment compared to Canadian-born white workers.

Interestingly, it was also discovered that Canadian-born visible minority men also faced an earnings gap of $8 \%$ relative to Canadian-born white men (Pendakaur \& Pendakaur, 1998, 520). This differential in earnings between racialized and non-racialized native- born populations is extremely alarming because the Canadian-born visible minority men hold Canadian credentials and experience that is highly valued in the economic sector. Altogether, the findings suggest that the earnings gap between male visible minority workers and white workers can be attributed to the economic discrimination in the labour market (Pendakaur \& Pendakaur, 1998, 520). However, in examining the earnings of women, it was determined that Canadian-born visible 
minority women enjoyed similar earnings relative to Canadian-born white women. Conversely, immigrant white women faced an earnings gap of $1 \%$ while immigrant visible minority women faced an earnings gap of 9\% in comparison with Canadian born white women (Pendakaur \& Pendakaur, 1998, 520). Therefore, except in the case of Canadian-born women, the overall findings suggest that the visible minority men and women have been positioned at the bottom of the economic hierarchy as they experience the largest income inequality with the Canadian born white group.

Asides from examining the earnings gap between Canadian-born visible minority and whites, it is also crucial to examine the differences in earnings within these two groups. A general trend observed between native born and immigrants was that visible minority groups have the lowest earnings, followed by Europeans and British (Nakhaie, 2006, 31). Native-born Latin American, Chinese, West Asian and South Asian ethno racial group had an earnings differential of over $10 \%$ less than British origin groups (Nakhaie, 2006, 34). Whereas, native born Greeks and Ukrainians had an earnings differential between $1 \%$ and 3\% less, while native born Balkans and Portuguese earned 5\% more than their British counterparts (Nakhaie, 2006, 34). These findings are of extreme significance as they imply that even though the earnings of native born European were equal or greater than British populations, the earnings of native born visible minorities were much lower (Nakhaie, 2006, 40). On the other hand, South Asian, South East Asian, Chinese, Vietnamese, Filipino, East Indian and Black immigrants, followed by Korean and Latin American immigrants faced the largest income disparity in comparison to the British origin immigrants (Nakhaie, 2006, 35). Interestingly, a large proportion of European immigrants including of Greeks and Ukrainians also experienced lower earnings than British origin counterparts (Nakhaie, 2006, 34). These findings have indicated that discrimination in the 
Canadian labour market does not simply occurs on the basis of race or skin colour as the earnings disadvantage was also experienced by white immigrants (Nakhaie, 2006, 38).

Moreover, research has revealed that the ethnicity-based earnings gap differs across Canada's three central metropolitan areas (CMAs). Both the groups of Canadian born visible minority and immigrant visible minority were subjected to a large earnings gap in Montreal, followed by Toronto and lastly by Vancouver (Pendaukaur \& Pendakaur, 1998, 541). Even though immigrant white men also faced an earnings gap, this seemed to be much smaller and experienced only in the cities of Montreal and Vancouver. In contrast, neither Canadian born visible minority women nor immigrant white women faced earnings differentials in any of the three CMAs. Nevertheless, immigrant visible minority women faced a large earnings gap in Montreal and Toronto in comparison to Canadian born white women (Pendaukaur \& Pendakaur, 1998, 541).

Another reliable indicator of racial discrimination is the systemic discriminatory practices utilized by employers in the recruitment and hiring procedures. Oreopolus (2011) conducted a study in which thousands of resumes were submitted online to job postings in Toronto with varied name, education, experience and language proficiency for the purposes of assessing discrimination in the employment procedures (Oreopolus, 2011, 153). It was revealed that English-named applicants with Canadian education and experience had the highest interview call back rate of 16\%. Similarly, English named applicants who listed only British experience also enjoyed equivalent call-back rates. However, there were lower call-back rates observed amongst ethnically named resumes with foreign education and foreign experience (Oreopolus, 2011, 162). This can be seen as the call back rate was dropped by $4 \%$ for Greek named resumes, $4.5 \%$ for Indian named resumes, $4.7 \%$ for Chinese named resumes and by 5.0\% for Pakistani named resumes (Oreopolus, 2011, 160). One possible explanation is that name-based discrimination 
occurs in employment procedures since English named applicants were generally preferred over foreign named applicants with similar levels of human capital. In particular, applicants' language skills are assessed by their names as "foreign sounding names may be overlooked due to the perception that their English language skills may be insufficient on the job site" (Oreopolus, 2011, 166). These findings suggest that employers have a tendency to devalue immigrants foreign credentials acquired in the non-traditional countries of India, China or Pakistan. Interestingly, Chinese named applicants adopted an English first name to counter the effects of skill devaluation. However, the call-back rate of Chinese applicants was still 3.5\% lower compared to applicants with English first and last names (Oreopolus, 2011, 161). This suggests that anglicizing of first names did not increase the chances of employment among ethnic-named applicants as their call-back rate was still drastically different from that of English named applicants.

Discrimination in employment practices may contribute to the underutilization of immigrant's skills, particularly the skills of ethnic and religious minorities. Khalema and Wannas (2003) have demonstrated that Muslim immigrants from non-traditional source regions of Middle East and Asia worked as professionals, engineers, medical doctors, bankers, accountants and business professionals prior to arrival in Canada (as cited in Ogbuagu, 2012, 8). However, at the post migration phase, most of these highly skilled immigrant minorities were marginalized into low wage employment as security guards, cleaning workers and taxi drivers. This indicates that discrimination may be a factor in preventing Muslim professional migrants in finding employment due to their easily identifiable Muslims or Arabic names (Ogbuagu, 2012, 8). In another experiment, Esses, Bennet-Abu Ayyash and Lashpina (2014) examined whether Muslim named resumes were likely to be perceived negatively during the hiring process. It was revealed 
that religious affiliation did not_impact the perception of an applicant's hard skills or soft skills for Canadian born applicants with Canadian experience (Esses et al., 2014, 58). The results were striking for immigrant applicants with foreign experience as it was observed that being a Muslim did not have an influence on immigrants' hard skills. In contrast, poorer perceptions of soft skills in the categories of problem solving, communication skills, and teamwork skills were generated for foreign trained Muslim immigrants (Esses et al., 2014, 58). More importantly, these perceptions of hard skills were amended for Muslim immigrants whose foreign credentials were not certified. This led to poorer perceptions of hard skills as well as soft skills, relative to Canadian born and trained individuals (Esses et al., 2014, 59). The overall findings have suggested that employers generally look for ways to express their pre-existing biases in the case of religious minorities. In situations where foreign trained immigrants foreign credentials were certified, certifications had positive effects of perceptions of hard skills while it had negative effects on soft skills. On the other hand, in situations when the foreign credentials of immigrants were not certified, it resulted in poorer perceptions of hard skill as well as soft skills (Esses et al., 2014, 59). 


\section{DISCUSSION \& CONCLUSION}

This research paper has argued that highly educated immigrants to Canada have experienced significant challenges in their social and economic integration. This has occurred largely because of the devaluation of immigrants' foreign work experience in the labour market. Furthermore, ethno-racial discrimination can also account for the higher rates of unemployment and lower rates of earnings among recent cohorts of highly educated immigrants. The deteriorating economic conditions of recent immigrants relative to native-born workers have raised important questions about the effectiveness of the points system and directions of the future of immigration policy. Therefore, a number of policy recommendations would be developed to align the admissions criteria under the points system with the employability criteria used by employers and professional organizations.

\section{Policy recommendations}

Recent immigrants to Canada have a greater likelihood to experience a decline in their economic performance during economic recessionary periods. One important way to improve the economic outcomes of recent immigrants is by adjusting the composition of immigrant inflow to be consistent with the macro labour market conditions. This means that there should be an increase in economic immigrants and a decrease in family class immigrants in times of economic booms. Likewise, there should be a decrease in economic immigrants and an increase in family class immigrants during economic recessionary periods (Picot \& Sweetman, 2012, 25). The rationale behind this recommendation is that economic immigrants are highly affected by macro labour market conditions as they are generally accepted for economic reasons (Picot \& Sweetman, 2012, 25). 
Over recent years, immigration policy in Canada has placed an increased emphasis on economic goals while it has comprised its commitment towards meeting family reunification goals. According to Alexander, Burleton \& Fong (2012), two thirds of immigrants were admitted under the economic class while only one-fifth were admitted under family class as permanent residents in 2010 (8). Therefore, Canada should increase the admission of immigrants under family class, as they tend to enjoy favourable economic outcomes. This can be evidenced as sponsored spouses and partners reported higher employment earnings in the first eight years after their arrival to Canada, relative to the spouses of economic immigrants (Citizenship \& Immigration Canada, 2014, 57). This may occur as sponsored spouses and partners have the social capital of family and friends to find employment in the knowledge-based economy.

Research has indicated that there has not been a clear breakdown in the objectives of the immigration policy. Traditionally, the Temporary Foreign Worker Program (TFW) and Provincial Nominee Program (PNP) have been oriented towards meeting the immediate needs of the labour market (Alexander, Burleton \& Fong, 2012, 9). In contrast, the Federal Skilled Workers Program (FSW) has been focused on meeting the long-term needs of the labour market (Alexander, Burleton \& Fong, 2012, 9). However, a change has occurred in recent years as FSWP has moved towards a short-term perspective (Picot \& Sweetman, 2012, 28). In light of these changes, short-term labour market needs should be made in consideration with long term needs to ensure that recent immigrants attain successful economic and social outcomes (Picot \& Sweetman, 2012, 28).

Provincial nominee programs serve an important means to meet the short-term labour market needs as well as demographic needs. PNP's have gained immense popularity over the years as only 477 immigrants were admitted in 1999, while 22,417 immigrants were admitted by 
2008 (Carter, Pandey and Townsend, 2010, 5). PNP's are a successful means to diverge immigration away from highly populated provinces such as B.C., Quebec and Ontario. There should be an increased use of these programs as it can promote the advantages of immigration and economic growth in small provinces and territories. PNP's should follow the lead of Manitoba Provincial Nominee Program (MPNP), in which there is a better job match, greater engagement of communities and a greater involvement of employers to recruit highly skilled immigrants in areas across the province (Carter, Pandey and Townsend, 2010, 11).

Since the inception of the points system, there has been an increase in immigrants from non-traditional countries in Asia, Africa, Central America and Eastern and Southern Europe. It has been reported that these racialized immigrants have faced the barriers of ethno-racial discrimination in finding employment. Therefore, immigrants employ the tactic of "resume whitening" to find employment in their respective fields such as IT, law, medicine and fiancé (Keung, 2016). This can be accomplished by adopting anglicized names or by removing work experience with ethnic groups on their resumes to remove any indicators of racial markers. Therefore, Paradakar (2016) has suggested that eliminating the name on a resume and labelling it with a unique ID in a job application can counter the effects of ethno-racial discrimination. This change should be accompanied by the implementation of written tests that assess whether an applicant has the skill set to meet job requirements. Such a tactic of "blind recruitment" would be helpful in reducing pre-existing biases or prejudices held by an employer held against visible minority immigrants (Paradakar, 2016).

Pre-migration services provided to immigrants prior to their arrival in Canada should contain accessible information on labour market outcomes of immigrants, with a focus on professional regulatory practices, job prospects, Canadian culture and values (Ogbuagu, 2012, 9). 
The pre-arrival services should also provide training on enhancing immigrants' soft skills in the areas of problem solving, communication and teamwork skills to prepare them for seeking employment in Canada (Esses et al., 2014, 60). Because Canadian experience is so important for future success, there should also be initiatives taken by licensing bodies and other labourdemanding institutions to promote positive attitudes towards immigrants' human capital skills among employers (Reitz, 2005, 422). This could include of actions plans that stress the value of recent immigrants foreign education and experiences to employers, regardless of immigrants race, skin colour or religious beliefs (Ogbuagu, 2012, 9). Additionally, there should also be government assisted workshops and campaigns designed to highlight employer's biases and prejudices and the consequences of discrimination in the workplace (Esses et al., 2014, 60).

There should also be greater coordination between governments and educational institutions such as universities and colleges. Bridging programs should be offered to recent immigrants as they can help them in transferring or in upgrading their human capital skills or in the labour market (Reitz, 2005, 420). One such bridging program for foreign trained pharmacists is available in University of Toronto's Faculty of Pharmacy, which is offered in collaboration with the Ontario College of Pharmacy and the Ontario Ministry of Training Colleges (Reitz, 2005,420 ). Furthermore, mentorship programs that offer training in the workplace would also be of great benefit to recent immigrants as they can assist immigrants to quickly learn Canadian values, business ethics and professional skills by shadowing other colleagues (Reitz, 2005, 421). Moreover, the programs would also provide recent immigrants with Canadian experience that is required in seeking employment in the secondary sector (Ogbuagu, 2012, 8); and that the data shows that this can be an important vehicle in determining an immigrants future and continued success in the Canadian labour market. 


\section{References}

Adamuti-Trache, M. (2015). Experiences of Highly Educated Immigrants. In H. Bauder and J. Shields (eds.), Immigrant Experiences in North America: Understanding Settlement and Integration (185-203). Toronto: Canadian Scholar's Press.

Alexander, C., Burleton, D. \& Fong, F. (2012). Knocking Down Barriers Faced By New Immigrants To Canada: Fitting the Pieces Together. TD Economics, 1-18.

Aydemir, A. (2003). Effects of business cycles on the labour market assimilation of immigrants. Ottawa, ON: Statistics Canada.

Aydemir, A., \& Skuterud, M. (2005). Explaining the deteriorating entry earnings of Canada's immigrant cohorts, 1966 2000. Canadian Journal of Economics, 38(2), 641-672. doi:10.1111/j.0008-4085.2005.00297.x

Banerjee, R., \& Lee, B. Y. (2012). Decreasing the recent immigrant earnings gap: The impact of Canadian credential attainment. International Migration, 53(2), 205-218. doi:10.1111/j.1468-2435.2012.00775.x

Banerjee, R., \& Verma, A. (2012). Determinants and Effects of Post-Migration Education among New Immigrants in Canada. Journal of International Migration and Integration, $13,59-82$.

Bauder, H. (2001). Culture in the labor market: Segmentation theory and perspectives of place. Progress in Human Geography, 25(1), 37-52. doi:10.1191/030913201672119762

Bauder, H. (2003). "Brain abuse", or the devaluation of immigrant labour in Canada. Antipode, 35(4), 699-717. doi:10.1046/j.1467-8330.2003.00346.x

Bloom, D. E., Grenier, G., \& Gunderson, M. (1995). The changing labour market position of Canadian immigrants. The Canadian Journal of Economics, 28(4b), 987-1005. 
Buzdugan, R., \& Halli, S. S. (2009). Labor market experiences of Canadian immigrants with focus on foreign education and experience. International Migration Review, 43(2), 366386. doi:10.1111/j.1747-7379.2009.00768.x

Carter, T., Pandey, M., Townsend, J., \& Institute for Research on Public Policy. (2010). The Manitoba provincial nominee program: Attraction, integration and retention of immigrants Institute for Research on Public Policy.

Cranford, C. J., Vosko, L. F., \& Zukewich, N. (2003). Precarious employment in the Canadian labour market: A statistical portrait. Just Labour, 3, 6-22.

Desjardins, D. \& Cornelson, K. (2011). Immigrant labour market outcomes in Canada: The benefits of addressing wage and employment gaps. Royal Bank of Canada, 1-8.

Esses, V. M., Bennett-AbuAyyash, C., \& Lapshina, N. (2014). How discrimination against ethnic and religious minorities contributes to the underutilization of immigrants' skills. Policy Insights from the Behavioral and Brain Sciences, 1(1), 55-62. doi:10.1177/2372732214550166

Ferrer, A. M., Picot, G., \& Riddell, W. C. (2014). New directions in immigration policy: Canada's evolving approach to the selection of economic immigrants. International Migration Review, 48(3), 846-867. doi:10.1111/imre.12121

Ferrer, A., \& Riddell, W. C. (2008). Education, credentials, and immigrant earnings. Canadian Journal of Economics, 41(1), 186-216. doi:10.1111/j.1365-2966.2008.00460.x

Frenette, M., \& Morissette, R. (2005). Will they ever converge? earnings of immigrant and Canadian-born workers over the last two decades. International Migration Review, 39(1), 228-257. doi:10.1111/j.1747-7379.2005.tb00261.x

Galabuzi, G. \& Teelucksingh, C. (2010). Social Cohesion, Social Exclusion, Social Capital. 
Region Municipality of Peel Immigration Discussion Paper. Retrieved July 24 from: https://region.peel.on.ca/social-services/pdfs/discussion-paper-1.pdf

Green, A. G., \& Green, D. A. (1995). Canadian immigration policy: The effectiveness of the point system and other instruments. The Canadian Journal of Economics, 28(4b), 10061041.

Green, A. G., \& Green, D. A. (1999). The economic goals of Canada's immigration policy: Past and present. Canadian Public Policy, 25(4), 425-451.

Green, A. G., \& Green, D. (2004). The goals of Canada's immigration policy: A historical perspective. Canadian Journal of Urban Research, 13(1), 102-139.

Green, D., and Worswick. (2009). Entry earnings of immigrant men in Canada: The roles of 1 labour market entry effects and returns to foreign experience. In T. McDonald, E. Ruddick, A. Sweetman, and C. Worswick (Eds.), Canadian Immigration: Economic Evidence for a Dynamic Policy Environment (77-100). Montreal QC: McGill-Queen's University Press.

Hawkins, F. (1975). Canada and immigration: Public policy and public concern. Montreal, QC: McGill-Queen's University Press.

Hinds, P. S., Vogel, R. J., \& Clarke-Steffen, L. (1997). The possibilities and pitfalls of doing a secondary analysis of a qualitative data set. Qualitative Health Research, 7(3), 408-424. doi:10.1177/104973239700700306

Hou, F., \& Picot, G. (2014). Annual levels of immigration and immigrant entry earnings in Canada. Canadian Public Policy / Analyse De Politiques, 40(2), 166-181. doi:10.3138/cpp.2013-017

Kelley, N. \& Trebilcock, M. (2010). The Making of the Mosaic: A History of Canadian Immigration Policy. Toronto: University of Toronto Press. 
Keung, N. (2016, March 17). Jobseekers resort to 'resumé whitening' to get a foot in the door, study shows. Toronto Star. Retrieved from https://www.thestar.com/news/immigration /2016/03/17/jobseekers-resort-to-resum-whitening-to-get-a-foot-in-the-door-studyshows.html

Law Commission of Ontario. (2012). Vulnerable Workers and Precarious Work. Toronto, ON.

Li, P. S. (2001). The market worth of immigrants' educational credentials. Canadian Public Policy / Analyse De Politiques, 27(1), 23-38.

Lusis, T., \& Bauder, H. (2010). Immigrants in the labour market: Transnationalism and segmentation. Geography Compass, 4(1), 28-44. doi:10.1111/j.1749-8198.2009.00277.x

Nakhaie, M. R. (2006). A comparison of the earnings of the Canadian native-born and immigrants, 2001. Canadian Ethnic Studies Journal, 38(2), 19.

Nakhaie, M. R., \& Kazemipur, A. (2012). Social capital, employment and occupational status of the new immigrants in Canada. Journal of International Migration and Integration, 14(3), 419-437. doi:10.1007/s12134-012-0248-2

Neuman, W. L., \& Robson, K. (2012). Basics of social research: Qualitative and quantitative approaches (2nd Canadian ed.) Pearson Allyn and Bacon.

Ogbuagu, B. C. (2012). Nice CV! you will hear from us: Canadian labor market and the phenomenology of the marginalized ethnic professional migrant. Journal of Social Sciences, 8(1), 1-12.

Oreopoulos, P. (2011). Why do skilled immigrants struggle in the labor market? A field experiment with thirteen thousand resumes. American Economic Journal: Economic Policy, 3(4), 148-171. doi:10.1257/pol.3.4.148 
Paradakar, S. (2016, March 22). How to root our racist hiring practices. Toronto Star. Retrieved from https:/www.thestar.com/opinion/commentary/2016/03/22/how-to-root-out-racisthiring-practices.html

Pendakur, K., \& Pendakur, R. (1998). The colour of money: Earnings differentials among ethnic groups in Canada. The Canadian Journal of Economics, 31(3), 518-548.

Pendakaur, R. (2000). Immigrants and the labour force: policy, regulation, and impact. Montreal, QC: McGill-Queen's University Press.

Poverty and Employment Precarity in Southern Ontario. (2015). The precarity penalty: the impact of employment precarity on individuals, households and communities -- and what to do about it. Toronto, ON: United Way Toronto.

Poverty and Employment Precarity in Southern Ontario (2013). It's more than poverty: Employment precarity and household well-being. Toronto, ON: United Way Toronto.

Phythian, K., Walters, D., \& Anisef, P. (2011). Predicting earnings among immigrants to Canada: The role of source country. International Migration, 49(6), 129-154. doi:10.1111/j.1468-2435.2010.00626.x

Picot, G. \& Sweetman, A. (2005). The deteriorating economic welfare of immigrants and possible causes: Update 2005. Ottawa, ON: Statistics Canada.

Picot, G., \& Sweetman, A. (2012). Making it in Canada: Immigration outcomes and policies. IRPP Study, 29, 1-31.

Reich, M., Gordon, D. M., \& Edwards, R. C. (1973). Dual Labor Markets: A Theory of Labor Market Segmentation. American Economic Review, 63(2), 359-365.

Reitz, J. G. (2001). Immigrant success in the knowledge economy: Institutional change and the 
immigrant experience in Canada, 1970-1995. Journal of Social Issues, 57(3), 579-613. doi:10.1111/0022-4537.00230

Reitz, J. G. (2005). Tapping immigrants' skills: New directions for Canadian immigration policy in the knowledge economy. Law and Business Review of the Americas, 11(3/4), 409-432.

Reitz, J. G. (2007). Immigrant employment success in Canada, Part I: Individual and contextual causes. Journal of International Migration and Integration / Revue De l'Integration Et De La Migration Internationale, 8(1), 11-36. doi:10.1007/s12134-007-0001-4

Reitz, J. G. (2007). Immigrant employment success in Canada, part II: Understanding the decline. Journal of International Migration and Integration / Revue De l'Integration Et De La Migration Internationale, 8(1), 37-62. doi:10.1007/s12134-007-0002-3

Roy, A. S. (1997). Job displacement effects of Canadian immigrants by country of origin and occupation. International Migration Review, 31(1), 150-161.

Samers, M. \& Snider M. (2015). Finding Work: The Experiences of Immigrants in North America. In H. Bauder and J. Shields (eds.), Immigrant Experiences in North America: Understanding Settlement and Integration (164-184). Toronto: Canadian Scholar's Press.

Schaafsma, J., \& Sweetman, A. (2001). Immigrant earnings: Age at immigration matters. Canadian Journal of Economics, 34(4), 1066-1099. doi:10.1111/0008-4085.00113

Sweetman, A. (2004). Immigrant source country educational quality and Canadian labour market outcomes. Ottawa, ON: Statistics Canada.

Teelucksingh, C. \& Galabuzi, G. (2005). Working precariously: the impact of race and immigrants status on employment opportunities and outcomes in Canada. Canadian Race Relations Foundations, 1-39.

Troper, H. (1993). Canada's immigration policy since 1945. International Journal, 48(2), $255-$ 
281.

Worswick, C. (2004). Immigrants' declining earnings: Reasons and remedies. C. D. Howe

Institute, 81, 1-9. 